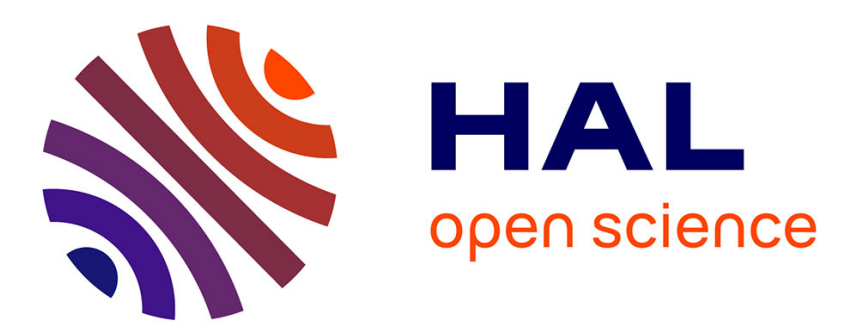

\title{
The onset of the rainy season and farmers' sowing strategy for pearl millet cultivation in Southwest Niger
}

Romain Marteau, Benjamin Sultan, Vincent Moron, Agali Alhassane, Seydou Traore, Christian Baron

\section{- To cite this version:}

Romain Marteau, Benjamin Sultan, Vincent Moron, Agali Alhassane, Seydou Traore, et al.. The onset of the rainy season and farmers' sowing strategy for pearl millet cultivation in Southwest Niger. European Geosciences Union (EGU), Apr 2011, Vienne, Austria. hal-00584850

\section{HAL Id: hal-00584850 https://hal.science/hal-00584850}

Submitted on 11 Apr 2011

HAL is a multi-disciplinary open access archive for the deposit and dissemination of scientific research documents, whether they are published or not. The documents may come from teaching and research institutions in France or abroad, or from public or private research centers.
L'archive ouverte pluridisciplinaire HAL, est destinée au dépôt et à la diffusion de documents scientifiques de niveau recherche, publiés ou non, émanant des établissements d'enseignement et de recherche français ou étrangers, des laboratoires publics ou privés. 


\section{The onset of the rainy season and farmers' sowing strategy for pearl millet cultivation in Southwest Niger}

Romain Marteau (1), Benjamin Sultan (2), Vincent Moron (3,4,5), Agali Alhassane (6), Seydou B. Traré (6), and Christian Baron (7)

(1) Centre de Recherches de Climatologie UMR 5210 CNRS - Université de Bourgogne - Dijon, France (Romain.Marteau@u-bourgogne.fr), (2) LOCEAN/IPSL - UMR 7159 - Université Pierre et Marie Curie, Paris, France, (3) CEREGE, UMR 6635, Europôle méditerranéen de l'Arbois, Aix-en-Provence, France, (4) International Research Institute of Climate and Society, Columbia university, New York, USA, (5) Institut Universitaire de France, (6) Centre Régional AGRHYMET, Niamey, Niger, (7) CIRAD, Montpellier, France

A multi-year (2004-2009) on-farm field campaign over 10 villages in South-West Niger, is analysed to investigate how rainfall determines the sowing date of pearl millet and the risk of sowing failure, and the relationships between sowing dates, onset dates (defined using various criteria) and observed yield and biomass at the end of the season. Even if some village uses frequently "dry sowings", i.e. sowing without any synchronous or anterior rainfall (till $40 \%$ in Tanabéri), most of parcels (73\% out of 1551 available cases) are sown during and just after a 2-day wet event receiving at least $10 \mathrm{~mm}$. In fact, there is a strong correlation $(\mathrm{r}=0.82-0.95$ depending on onset definition) between spatial average of onset dates and the one of sowing dates. Most of the failed sowings $(\sim 22 \%$ of total sowings) are related to dry spells longer than 10 days after an initial 2-day wet spell. Simulations with the crop model SARRA-H show that the ideal sowing date, retrospectively computed as the one maximizing simulated yield, is slightly later (about 6 days) than the observed one for this dataset. Despite the large intra-village variance and the relatively weak inter-annual signal in onset dates and seasonal amount, there is a small tendency to observe weaker yields and especially weaker amounts of biomass, when onset is anomalously late. But crop simulations show also that a too early sowing, as for example when at least $90 \%$ of rainfall stations are simultaneously wet (i.e. at least $1 \mathrm{~mm}$ in 2 consecutive days) for the first time, do not maximize simulated yield, because of the risk of long-lasting post-onset dry spells. 